\section{Birlesik Dünya Arastırma New Trends and Issues BD - CENTER Proceedings on Humanities and Innavasyon ve Yayınıılık Merkezi \\ Social Sciences}

Volume 7 No 1 (2020) 249-262

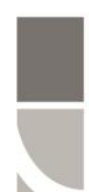

New Trends

and Issues Proceedings

on Humanities \& Social Sciences

www.prosoc.eu

Selected Paper of 12th World Conference on Educational Sciences (WCES-2020) 06-08 June 2020, Istanbul Ayvansaray

University, Istanbul, Turkey

\title{
Introducing the fundamental theorem of arithmetic through a mobile game
}

Mustafa Gök *, Yüzüncü Yıl Üniversitesi, Eğitim Fakültesi, İlköğretim Bölümü, İlköğretim Matematik Öğretmenliği Anabilim Dalı, Turkey https://orcid.org/0000-0001-9349-4078

\section{Suggested Citation:}

Gök, M. (2020). Introducing the fundamental theorem of arithmetic through a mobile game. New Trends and Issues Proceedings on Humanities and Social Sciences. 7(1), pp 249-262. DOI: 10.18844/prosoc.v\%vi\%i.4940

Received from October 25, 2019; revised from March 05, 2020; accepted from June 29,2020.

Selection and peer review under responsibility of Assoc. Prof. Dr. Jesus Garcia Laborda, University of Alcala, Spain. (C2020 Birlesik Dunya Yenilik Arastirma ve Yayincilik Merkezi. All rights reserved.

\begin{abstract}
There is an increasing trend towards the use of mobile games in education. Presenting knowledge with mobile games requires many variables to be employed. These processes should be made more rigorous in domains such as mathematics where knowledge is abstract. The aim of this study is to develop an application to introduce the Fundamental Theorem of Arithmetic through a mobile game. The findings of the research show that the Fundamental Theorem of Arithmetic can be introduced with the developed mobile game. When the mobile game is evaluated in terms of mathematical knowledge, it is determined that while the constraints and conditions determined in the game hide the mathematical knowledge. In this sense, some game examples are given in this study and some models related to feedbacks that students can take in these games are presented.
\end{abstract}

Keywords: a-didactical situations, mobile games, mathematics teaching, mathematical concepts;

\footnotetext{
*ADDRESS FOR CORRESPONDENCE: Mustafa Gök, Yüzüncü Yıl Üniversitesi, Bardakçı, Yüzüncü Yıl Üniversitesi Kampüsü, 65090 Tuşba/Van, Turkey E-mail address: gkmstf@gmail.com
} 
Gök, M. (2020). Introducing the fundamental theorem of arithmetic through a mobile game. New Trends and Issues Proceedings on Humanities and Social Sciences. 7(1), pp 249-262. DOI: 10.18844/prosoc.v\%vi\%i.4940

\section{Introduction}

This study is based on three main supports: mathematics teaching, game and technology. The latter two are used to effectively conduct the previous one. It is emphasized that there is a further dimension of the means-ends relationship between games and teaching mathematics. Pointing to this reality, Bishop (1991) draws attention to the mathematical connections in games, and most mathematicians regard games as mathematical because they are rules-based behaviors. With this awareness, most mathematicians designed mathematical games. Holton et al. (2001) described the mathematical game as a tool that requires the use of mathematical processes to overcome problems and to produce ideas with experimental or creativity and to reach a solution.

Why is it important to present mathematical concepts through games? Traditional teaching does not lead to fast and well learning in order to achieve a goal for students in the future when compared to teaching mathematics through the game (Gee, 2003). Games are activities where effective learning takes place by enabling the individual to discover himself, his environment and new worlds (Tanja, Euđen, \& Jelena, 2017). In addition to many variables such as motivation (Papastergiou, 2009; Heshmati, Kersting \& Sutton, 2018), achievement (Kim \& Fe, 2017), problem-solving and programming skills of students (Hong \& Chu, 2017), the teaching approach with the game has positive results on the permanence of learning (Hsu, Chen \& Cao, 2017).

The instructional approach through the game has a broad spectrum, including games in which technological tools are used. The integration of technology in this process provides a more solid basis for mathematics education, involving some predictable consequences. One of these consequences is that the integration of technology into education has changed our approach to mathematics teaching and led to the emergence of innovative learning environments. Hence, mobile games can be considered in this context.

It can be noted that today, there is an increasing trend towards the use of mobile games in mathematics teaching (Diah, Ehsan, \& Ismail, 2010). This is because of the fact that students become accustomed to mobile games, and they are accessible via internet access and playable in any place. Referring to some of these features, mobile games are defined as game applications played on small handheld computers (e.g. smartphones and tablets) with wireless communication functions (Jeong \& Kim, 2009).

It is stated in the literature that mobile games positively affect attitudes and motivation towards mathematics, increase attendance (Cahyono, 2018), and provide support in achieving learning outcomes (Kluge \& Dolonen, 2015). However, it is stated that teachers have very few mathematical game-like tools for teaching complex mathematical concepts (Brezovszky et al., 2019).

These games have great potential to allow students to build mathematical knowledge themselves. As of today, despite the rapid progress in the technology and software fields, there are either limited numbers or no mobile games where students can make sense of mathematical objects in many subjects. The starting point of this study is the idea of offering a new example that contributes to filling this gap. 
Gök, M. (2020). Introducing the fundamental theorem of arithmetic through a mobile game. New Trends and Issues Proceedings on Humanities and Social Sciences. 7(1), pp 249-262. DOI: 10.18844/prosoc.v\%vi\%i.4940

\subsection{The Fundamental Theorem of Arithmetic}

The fundamental theorem of arithmetic, or the unique factorization theorem, states that any natural number greater than 1 can be written as a unique product (apart from the order in which the factors appear) of prime numbers (Burton, 2010).

An acquisition takes place at the 6 th grade level in the domain of learning numbers and operations in the mathematics curriculum, "determines the prime factors of natural numbers"(MoNE, 2018). This acquisition is a reflection of the fundamental theorem of arithmetic at the secondary level. The aim of this study is to develop an application to introduce the fundamental theorem of arithmetic through a mobile game.

\section{Method}

In this study, qualitative research method was used. In the development process of mobile game, Brousseau's (2002) Theory of Didactical Situations (TDS) and Prensky's (2001) game development criteria were used. Theory of Didactical Situations (TDS) offers a game-based learning approach in mathematics teaching (Brousseau, 2002). The mobile game designed according to the theory is seen as a part of the millie in the teaching of mathematical knowledge. In this context, it is provided that mathematical knowledge presents in a situation where it is embedded in a mobile game. These situations, in which the expectations of the teacher are ignored and the students are confronted with the object of knowledge (for example, a designed game), are called adidactic situations in theory (Sensevy et al., 2005). Adidactic states can be used functionally in creating student-centered environments (Laborde, 2007). In this study, a mobile game was designed to create such an milieu. However, the criteria suggested by Prensky (2001) were used in the development of mobile games. These criteria include 1. Rules, 2. Objectives and aims, 3. Outputs and feedback, 4. Conflict, competition, challenge, and opposition, 5. Interaction, 6. Representation or story. The rules of the games are the most basic features that distinguish them from free plays. The rules include constraints and conditions. These force players to follow certain paths to achieve goals, and players follow these paths. Objectives and aims similarly distinguish a game from other plays and non-purpose-built games. Outputs and feedback are about how to measure progress against goals. Most of the attractiveness of the games provides win-lose situations, which can be considered as the intermediate element of this process. Conflict, competition, challenge, opposition refers to the problem situation in the games or the tasks to be completed. Problem situations or tasks should be organized in accordance with the abilities of the players. In other words, they should be neither as simple as they would be boring, nor too difficult for them to solve. Interaction has two aspects. First, the interaction between the player and the computer resulting from the feedback given in the game, which goes through a critical review by the learners. The second is the social aspect of the game, which consists of experiences, achievements, and other related shares in one way or another. Representation that includes the narrative or story elements can be explained as what the game is about.

In the game designed in the study, these components were taken into consideration and presented in the context of reproduction of a bacterium under certain conditions. A similar version of the game that can be played with paper and pencil is presented in Appendix 1. 


\subsection{Game Design and Coding}

Game design started with the charcoal drawing of the screens to be used in the game. Adobe Illustrator was often used for background images and icons. The coding process was implemented using Java language in the Android Studio environment. Android version 2.1 was used to code games. In this study, didactic model given in Figure 1 was used in game design process (Gök, 2019).



Figure 1. Didactic Model in Game Design

In this model, game design starts with the aim of mathematical knowledge. In this respect, a number of constraints and conditions are created that have the potential to reveal mathematical knowledge, and mathematical knowledge is presented (implicitly) embedded in a problem situation. In other words, the problem situation bridges mathematical knowledge and digital milieu and the conditions created for the emergence of mathematical knowledge constitute the rules of the game. This part constitutes the internal structure of the game because the digital environment is associated with mathematical knowledge. The internal structure of the game makes the player intuitively feel that the game has a purpose and is worth the effort. In this context, the player's effort to reach this goal motivates him to play. 
In the process of interacting with the game (the start, development and finish cycle in each game) it gives the player many different feedback. Feedback such as computer and player choices, difficulty level of the game and the points can be counted in this context. All these feedbacks form the external structure of the game, that is, the visible dimension of the game. These can be expressed as the player's struggle with the digital environment. Digital media reflecting the intersection of internal and external structures in the game can be described as the heart of the model.

It can be stated that each game performed by the player will lead to the rediscovery of the problem situation through reflection and the generation of new strategies for eliminating the problem caused by the player. In this way, the dynamic structure in the environment is preserved.

The first moments on the time scale of the game are problematic for the player. However, with the feedback received from the digital environment in the following process, it is provided to produce strategies that provide the problem situation in the game. By validating these strategies in the context of the game, some implicit models are often reached and as a result, mathematical knowledge is discovered in the context of the game.

\section{Bacterial Colony Game}

The game is played solo. After clicking on the game icon, three different levels appear. These levels are designed from easy to hard and from level 1 to level 3. In Level 1, on the first game screen and in every subsequent game, initially, 1 bacteria seen in blue is positioned in the upper left corner of the game area. The screen is organized to fit 100 bacteria in total. In the row and column, there are buttons with the numbers 1, 2, 4, and 6 (Figure 2). When these buttons are pressed, the number of bacteria increases according to a particular rule. However, in each reproduction process, new bacteria are derived in a different color. The buttons on the top perform replication to the right (Right Direction Replication Buttons: RDRB), and the buttons on the side of the screen perform replication down (Down Direction Replication Buttons: DDRB). Reproduction is carried out at any time on any bacteria or all of the bacteria. In each game, the number of bacteria colonies to be reached is given at the top of the screen. To win the game, it is necessary to multiply the number of bacteria written on the top of the screen from 1 bacterium through the buttons given in the rows and columns in the game field on the screen.

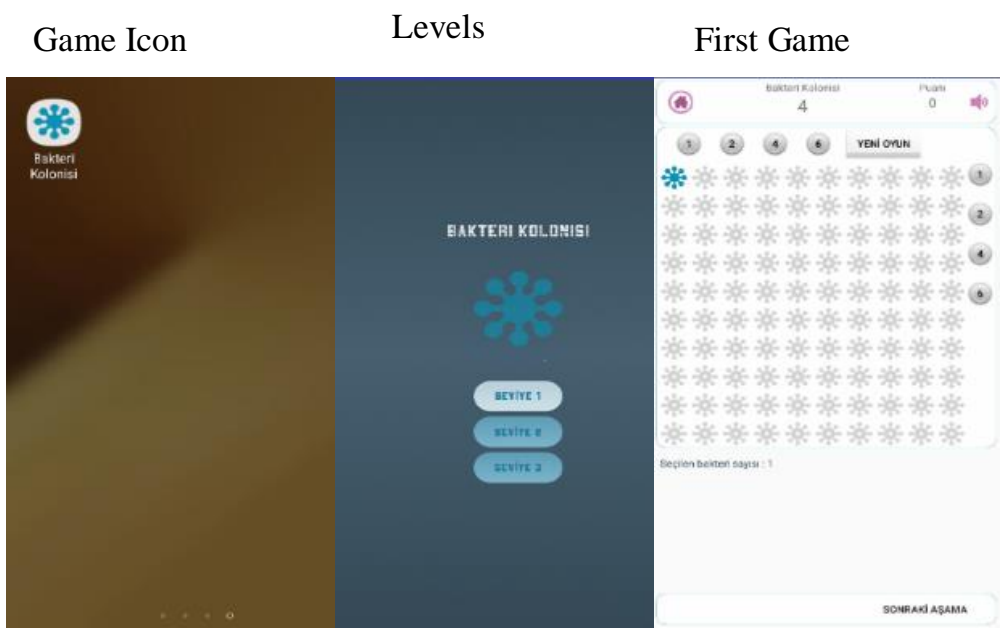

Figure 2. Icon, Levels, and First Game of the Bacterial Colony Game 
Figure 2 shows the icon, levels (Level 1, Level 2, and Level 3), and the beginning of the first game of the bacterial colony game. At the top of the game screen there are the number of bacteria and points to be reached. Just above the playing area are the right direction duplication buttons $(1,2,4$, and 6$)$ and the new game button. Next to the playing area are the down direction duplication buttons. Just below the playing area is the number of bacteria present on the playing field at any given moment. In addition, the main menu is located in the upper left corner of the screen, the voice-over in the upper right corner announcing the selection, and the switch to the next level button is located in the lower right corner.

\subsection{Constraints and Conditions in the Game}

The objective of this game is to obtain the bacterial colony indicated on the screen by producing new bacteria from a bacterium using the Right Direction Reproduction Buttons and Down Direction Reproduction Buttons. It is not possible to place more than 10 bacteria in rows and columns. If this is exceeded, a warning appears on the screen: "Please select another number. Column/Row is not available". In each game, the first bacterium in blue is positioned on the top left of the screen. Pressing the right direction replication buttons creates new bacteria on the right of this bacterium.

- If the Right Direction Replication Button 1 (RDRB1) is pressed after the first position, it becomes “**”.

-If the Right Direction Replication Button 2 (RDRB2) is pressed after the first position, it becomes “***".

-If the Right Direction Replication Button 4 (RDRB4) is pressed after the first position, it becomes “*****".

-If the Right Direction Replication Button 6 (RDRB6) is pressed after the first position, it becomes "*******"

-Each reproduction is performed in a different color. In this context, the color sequence is blue, purple, green, orange, black, red, and yellow, so that the starting is always blue. For example, after pressing the right direction reproduction button 2 twice after the first position, "*********" appears on the game screen. Similarly, when the down-reproduction buttons are pressed, the sequence of the bacterial colony is positioned on the same color and number but from the top down. Figure 3 shows some different combinations of 6 various bacterial colonies in this game.

In Figure 3, three of the six different ways of creating 6 bacteria are given. The game is won when the number of bacteria in the colony is reached. When the number of bacteria in the colony is reached, a "congratulations" text appears on the screen. The buttons in this game only increase the number of bacteria present. In this respect, there is no possibility of reducing the number of bacteria. If the number of bacteria targeted to be reached is exceeded during the game, the game is lost. Figure 3 shows that all games are lost. 


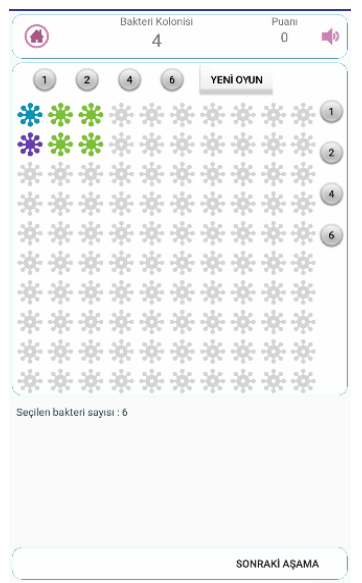

DDRB1, RDRB2

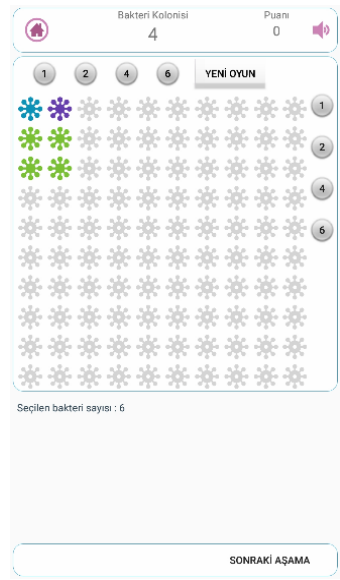

RDRB1, DDRB2

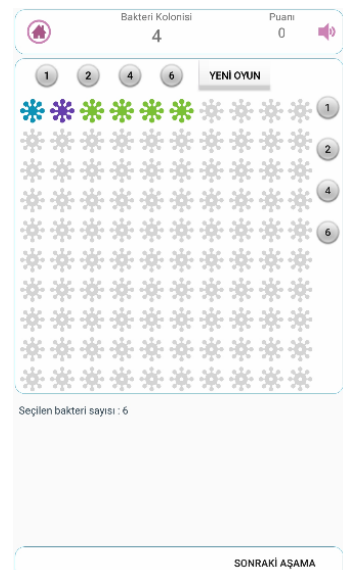

RDRB1, RDRB2

Figure 3. Different Combinations of 6 Bacteria in the Bacterial Colony Game

\subsection{Levels and Scoring in the Game}

The game consists of three levels, from easy to hard.

Level 1 (Easy): The number of bacterial colonies to be reached at this level is $\{4,6,9,10,14,15,21$, $25,35,49\}$. Each number in the set is a level that must be passed in the game. Therefore, there are 10 stages at this level. These numbers were not randomly generated. Note that each number has only two prime factors (primes can be the same).

Level 2 (Normal): The number of bacterial colonies to be reached at this level is defined as $\{8,12,18$, $20,27,28,45,50,63\}$. Therefore, there are 9 stages at this level. The numbers used in these steps have three prime multipliers (which may be the same).

Level 3 (Hard): The number of bacterial colonies to be reached at this level is $\{16,24,40,54,56,81$, $100\}$. There are 7 stages in this level. The numbers used in these stages have four prime multipliers (no obligation to be different).

The bacterial colony game has three levels and a total of 26 stages in the levels. The numbers used in the stages at each level increase in an ascending way. By pressing the button in the lower right corner of the screen, players can move to a different level or next stages.

Games are scored based on levels. Every game in Level 1, 2, and 3 is worth 2 points, 3 points, and worth 4 points, respectively. The following section examines a sample of the game at each level and the methods that can be used in these games.

\subsection{Game 1}

Some solutions for bacterial colony number 10 at Level 1 are as follows: RDRB1 $\rightarrow$ DDRB4, RDRB4 $\rightarrow$ DDRB1, DDRB1 $\rightarrow$ RDRB4, DDRB4 $\rightarrow$ RDRB1, RDRB1 $\rightarrow$ RDRB4, or DDRB1 $\rightarrow$ DDRB4. Points are earned only when the number of bacteria to be reached is achieved in the game. 2 points are earned 
for each game played correctly in stages at Level 1. Two examples of correct solutions are given in Figure 4.

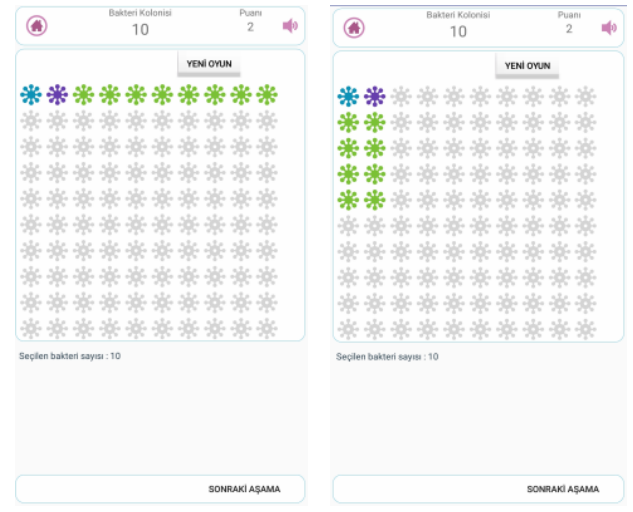

Figure 4. Two Different Methods for Stage 4 in Level 1

Method 1: This method is based on the positioning of all bacteria in just one row or column. Therefore, we try to create a $1 \times 10$ or 10x1 matrix. This process can be applied in 4 different ways in the game.

Method 2: This method is based on the positioning of bacteria as a $2 \times 5$ or $5 \times 2$ matrix. This process can be implemented in 4 different ways in the game.

\subsection{Game 2}

Some solutions for bacterial colony number 12 at Level 2 are as follows: RDRB1 $\rightarrow$ RDRB1 $\rightarrow$ DDRB2, $\mathrm{RDRB} 2 \rightarrow \mathrm{DDRB} 1 \rightarrow \mathrm{DDRB} 1, \mathrm{RDRB} 1 \rightarrow \mathrm{RDRB} 2 \rightarrow \mathrm{DDRB} 1, \mathrm{RDRB} 2 \rightarrow \mathrm{RDRB} 1 \rightarrow \mathrm{DDRB} 1, \quad \mathrm{DDRB} 1 \rightarrow \mathrm{DDRB} 2 \rightarrow$ RDRB1, or DDRB2 $\rightarrow$ DDRB1 $\rightarrow$ RDRB1. 3 points are earned for each game played correctly in stages at Level 2. Due to the limitation of the playing area, some solutions could not be carried out, i.e., the sequence of bacteria in the same row or column 12. Two examples of possible solutions are given in Figure 5.

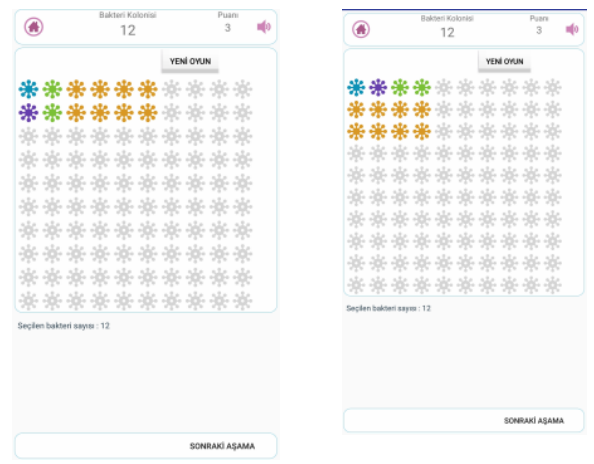

Figure 5. Two Different Methods for Stage 2 in Level 2 
Method 1: This method involves positioning all bacteria in only one row or column. However, it did not appear due to the limited play area.

Method 2: This method is based on the positioning of bacteria as a $2 \times 6$ or $6 \times 2$ matrix. This process can be performed in 8 different ways.

Method 3: This method is based on the positioning of bacteria as a $3 \times 4$ or $4 \times 3$ matrix. This process can be performed in 4 different ways.

\subsection{Game 3}

Some solutions for bacterial colony number 100 at Level 3 are as follows: RDRB4 $\rightarrow$ DDRB4 $\rightarrow$ RDRB1 $\rightarrow$ DDRB1,

RDRB1 $\rightarrow$ DDRB4 $\rightarrow$ RDRB4 $\rightarrow$ DDRB1. 4 points are earned for each game played correctly in stages at Level 2. Due to the limitation of the playing area, some solutions could not be carried out, for example, placing 100 bacteria in the same row or column or 25 bacteria in each of the 4 rows. One of the possible solutions is given in Figure 6.

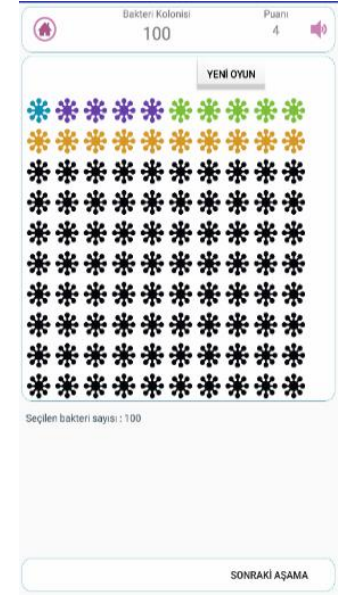

Figure 6. A Method for Stage 7 in Level 3

Method 1: This method attempts to create a $1 \times 100$ or $100 \times 1$ matrix. However, due to the limitations of the playing area, this method could not be used. Similarly, the matrices $2 \times 50,4 \times 25$, and $5 \times 20$, and their inverses could not be shown due to the limitation in the game.

Method 2: This method is based on the positioning of bacteria in the form of a $10 \times 10$ matrix. This process can be applied in 20 different ways.

\subsection{Feedback That Mobile Game Offers to Players}

In pedagogical terms, the bacterial colony game provides many possibilities for the learners to construct mathematical knowledge. These include the following:

1. Easy adaptation to the game since a situation from daily life is examined.

2. Not too complicated game rules. 
3. The game cannot be solved immediately (This is because the rule on the reproduction of the bacterium is discovered in the process of trial and error. This requires an in-depth examination of some processes.)

4. Multiple methods to solve any stage at any level of the game.

5. Since the game is based on a win-lose strategy, the players can get feedback on the action they are performing.

6. Following game actions separately as each move is represented in different colors.

7. Scoring in the game keeps sustainability alive.

8. Keeping the dynamic structure in the environment due to the levels in the game from easy to hard.

9. Because the game is played on the touch screen, it offers ease of use and leads the player to interact with mathematical objects.

On the other hand, the game also has some limitations. Some of these can be listed as organizing the playing field in the form of a 10x10 matrix, in that some solution paths are not available, and that numbers with only prime numbers $2,3,5$, and 7 in their multipliers can be obtained. For example, 11 bacteria cannot be reached in this game.

\subsection{Mathematical Knowledge Hidden in the Mobile Game}

In this game, some natural numbers with multipliers $2,3,5$, and 7 can be constructed on a $10 \times 10$ matrix layout. The numbers $1,2,4$, and 6 , which allow the bacteria to multiply in the game, correspond to the prime numbers $2,3,5$, and 7 when the starting bacteria are included. Thus, in the bacterial colony game, the Fundamental Theorem of Arithmetic, which is defined by the rule that every natural number greater than 1 is either a prime or a product of primes (Devlin, 2003), was discovered in some of the limited set of numbers (numbers from 1 to 100).

\subsection{Suggestions for Using the Game in the Classroom}

The game can be applied according to the stages that Brousseau (2002) defines in the framework of the Theory of Didactic Situations.

1. Devolution: The game and its rules are explained.

2. Action: Students play the game. In this process, they acquire some implicit strategies that bring success in the game.

3. Formulation: Strategies achieved during the action stage are clearly shared with the class.

4. Validation: It is explained to another person why the strategies developed by the students during the formulation stage are valid.

5. Institutionalization: The activity is completed by explaining the mathematical knowledge underlying the game. 
Gök, M. (2020). Introducing the fundamental theorem of arithmetic through a mobile game. New Trends and Issues Proceedings on Humanities and Social Sciences. 7(1), pp 249-262. DOI: 10.18844/prosoc.v\%vi\%i.4940

\section{Discussion and Conclusion}

In this study, it has been shown that an effective start to the fundamental theorem of arithmetic can be achieved through a mobile game. In addition, it can be suggested that mobile game has an innovative approach in terms of having multiple solutions, providing an approach to the application process, offering feedback to the player and allowing the player to discover pieces of mathematical knowledge. Besides, the mobile game also contains clues about how mathematical knowledge can be hidden within the game.

When the mobile game is evaluated in terms of mathematical knowledge, it is determined that while the constraints and conditions determined in the game hide the mathematical knowledge on the one hand. On the other hand, it has been determined that it plays an important role in the formation of the problem situation. In addition, in the process of mobile game development, the feedback mechanism created provides a dynamic way to reach the mathematical knowledge hidden beyond the mobile game. In this sense, some game examples are given in this study and some models related to feedbacks that students can take in these games are presented. It is thought that the introduction of mathematical concepts in mathematics teaching through mobile games instead of presenting in traditional ways may have many positive reflections. For example, mobile games can play a facilitating role in motivating students to learn and teaching the models of mathematical objects.

Teaching mathematical concepts through mobile games is important in three basic ways. The first is that in the digitalized world, technological developments change our approach to teaching mathematics (Ersoy, 2005) and the readiness of students shifts to the common denominator technologically based tools of which is used (Balacheff \& Kaput, 1997). The second is that, compared to traditional ways, in mathematics teaching environments using technological tools, students have more positive results in terms of many variables such as success, attitude, and motivation (Cahyono, 2018; Wijers et al., 2010; Kluge \& Dolonen, 2015; Heshmati, Kersting \& Sutton, 2018; Kim \& Fe, 2017). Wijers et al. (2010) stated that in a game used mobile technologies, students learn to use GPS, to read maps and to construct quadrilaterals. Gök, İnan, and Akbayır (2020) developed a mobile game for teaching the Euclid Division in an effective student-centered environment. In the study, it was emphasized that this process should be organized carefully. Finally, through mobile technologies, students can access information faster and from any location they wish. On the other hand, studies for teaching mathematical concepts with mobile technologies are still very new and open to development. In this study, unlike other studies, it is clearly explained how a specific mathematical concept can be given in the context of the game and how the design elements will be used in this process.

In conclusion, in this study, it can be stated that mathematical knowledge can be promoted effectively through mobile games and this approach presents many positive indicators for students. Ultimately, it is thought that this game could guide new studies on how mathematical knowledge can be designed with a conceptual approach.

\section{References}

Balacheff, N. \& Kaput, J. J. (1997). Computer based learning environment in mathematics. In Bishop, A. (ed.) International Handbook in Mathematics Education (pp. 469-501). Dordrecht: Kluwer Academic publisher.

Bishop, A. J. (1991). Environmental activities and mathematical culture. In Mathematical Enculturation (pp. 2059). Springer, Dordrecht. https://link.springer.com/chapter/10.1007/978-94-009-2657-8 2 
Gök, M. (2020). Introducing the fundamental theorem of arithmetic through a mobile game. New Trends and Issues Proceedings on Humanities and Social Sciences. 7(1), pp 249-262. DOI: 10.18844/prosoc.v\%vi\%i.4940

Brezovszky, B., McMullen, J., Veermans, K., Hannula-Sormunen, M. M., Rodríguez-Aflecht, G., Pongsakdi, N., et al. (2019). Effects of a mathematics game-based learning environment on primary school students' adaptive number knowledge. Computers \& Education,128, 63-74. https://doi.org/10.1016/J.COMPEDU.2018.09.011.

Brousseau, G. (2002). Theory of didactical situations in mathematics. In N. Balacheff, M. Cooper, R. Sutherland \& V. Warfield (Eds). (pp.15-45). Dordrecht, The Netherlands: Kluwer Academic.

Burton, D. M. (2010). The History of Mathematics: An Introduction (seventh edition). Boston, MA: McGraw-Hill.

Cahyono, A. N. (2018). Learning Mathematics in a Mobile App-Supported Math Trail Environment. Cham (Switzerland): Springer International Publishing

Devlin, K. (2003). Sets, functions, and logic: An introduction to abstract mathematics (3rd. Ed.). Chapman and Hall/CRC.

Diah, N. M., Ehsan, K. M., \& Ismail, M. (2010). Discover mathematics on mobile devices using gaming approach. Procedia-Social and Behavioral Sciences, 8, 670-677. Doi:10.1016/j.sbspro.2010.12.093

Ersoy, Y. (2005). Matematik eğitimini yenileme yönünde ileri hareketler-l: teknoloji destekli matematik öğretimi [Movements for innovations of mathematics education-1: Technology supported mathematics teaching]. The Turkish Online Journal of Educational Technology, 4 (2), 51-63.

Gee, J. P. (2003). What video games have to teach us about learning and literacy. New York: Palgrave Macmillan.

Gök, M. (2019). Matematik eğitiminde didaktik durumlar teorisi ışığında eğitsel bir mobil oyun tasarımı ve bir model önerisi [An educational mobile game design and a model proposal in the light of the theory of didactical situations in mathematics education]. In H.í. Özok \& C. Aladağ (Eds.), Eğitim pratiğimiz üzerine araştırmalar [Research on our educational practice] (pp. 256-269). Ankara: Pegem Akademi.

Gök, M., İnan, M., \& Akbayır, K. (2020). Sınıf öğretmeni adaylarına Öklid bölmesinin bir mobil oyunla tanıtılması [Introduction of Euclid division to the prospective primary school teachers through a mobile game]. Cumhuriyet International Journal of Education, 9(1), 219-242. http://dx.doi.org/10.30703/cije.560761

Heshmati, S., Kersting, N., \& Sutton, T. (2018). Opportunities and challenges of implementing instructional games in mathematics classrooms: Examining the quality of teacher-student interactions during the cover-up and un-cover games. International Journal of Science and Mathematics Education, 16(4), 777-796. DOI $10.1007 /$ s10763-016-9789-8

Holton, D., Ahmed, A., Williams, H., \& Hill, C. (2001). On the importance of mathematical play. International Journal of Mathematical Education in Science and Technology, 32(3), 401-415. doi: 10.1080/00207390118654

Hong, T. Y., \& Chu, H. C. (2017, June). Effects of a Situated 3D Computational Problem-Solving and Programming Game-Based Learning Model on Students. In 2017 6th IIAl International Congress on Advanced Applied Informatics (IIAI-AAI) (ss. 596-600). IEEE. Doi: 10.1109/IIAI-AAI.2017.96

Hsu, C. F., Chen, C. M., \& Cao, D. (2017, June). Effects of Design Factors of Game-Based English Vocabulary Learning APP on Learning Performance, Sustained Attention, Emotional State, and Memory Retention. In 2017 6th IIAl International Congress on Advanced Applied Informatics (IIAI-AAI) (ss. 661-666). IEEE. Doi: 10.1109/IIAI-AAI.2017.53

Jeong, E. J., \& Kim, D. J. (2009). Definitions, key characteristics, and generations of mobile games. In D. Taniar (Ed.), Mobile computing: Concepts, methodologies, tools, and applications (pp. 289-295). Hershey, PA: IGI Global.

Kim, H., \& Ke, F. (2017). Effects of game-based learning in an OpenSim-supported virtual environment on mathematical performance. Interactive Learning Environments, 25(4), 543-557.

https://doi.org/10.1080/10494820.2016.1167744 
Gök, M. (2020). Introducing the fundamental theorem of arithmetic through a mobile game. New Trends and Issues Proceedings on Humanities and Social Sciences. 7(1), pp 249-262. DOI: 10.18844/prosoc.v\%vi\%i.4940

Kluge, A. and Dolonen, J. (2015). Using mobile games in the classroom: The good and the bad of a new math language. In H. Crompton and J. Traxler (Eds.), Mobile learning and mathematics: Foundations, design, and case studies (pp.106-121). New York: Routledge.

Laborde, C. (2007). Towards theoretical foundations of mathematics education. ZDM Mathematics Education 39, 137-144. https://doi.org/10.1007/s11858-006-0015-y

MoNE (2018). Matematik dersi ögretim programı (ilkokul ve ortaokul 1, 2, 3, 4, 5, 6, 7 ve 8. Sınıflar). Retrieved March 3 2020, http://mufredat.meb.gov.tr/Dosyalar/201813017165445MATEMAT\%C4\%BOK\%20\%C3\%96\%C4\%9ERET\%C4\%BOM\%20PROGRAMI\%202018v.pdf

Papastergiou, M. (2009). Digital game-based learning in high school computer science education: Impact on educational effectiveness and student motivation. Computers \& Education, 52(1), 1-12. https://doi.org/10.1016/i.compedu.2008.06.004

Prensky, M. (2001). Digital Game-Based Learning. McGraw-Hill, New York.

Sensevy, G., Schubauer-Leoni, M. L., Mercier, A., Ligozat, F., \& Perrot, G. (2005). An attempt to model the teacher's action in the mathematics class. Educational Studies in Mathematics. 59, 153-181. DOI: 10.1007/s10649-005-5887-1

Tanja, N., Euđen, Činč, \& Jelena, P. (2017). The Role and Significance of Game in Early Development of Preeschool Children. PUPIL: International Journal of Teaching, Education and Learning, 1(1), 98 -112. Retrieved from https://grdspublishing.org/index.php/PUPIL/article/view/964

Wijers, M., Jonker, V., \& Drijvers, P. (2010). MobileMath: Exploring mathematics outside the classroom. ZDM, 42(7), 789-799. $\quad$ https://doi.org/10.1007/s11858-010-0276-3

Appendix 1. Playing the Bacterial Colony Game with Paper and Pen

This game can be played by two people or two groups in the context of a contest in which the first person to complete the task will win. In the starting position, 1 piece of bacteria (appears as A) is required to reproduce bacterium/bacteria in accordance with the following rules.

1. Reproduction should be done to the right or down.

2. Reproduction should be applied to all existing bacteria.

3. Reproduction at any time is carried out by increasing the current bacteria by $1,2,4$, and 6 times. This should be written under the arrow between the letters (For example, in a sample reproduction such as $\mathrm{A}_{i}^{\mathrm{B}} \mathrm{C}, 1$ reproduction was applied to the starting 1 bacterium, and 1 bacterium increased in the colony, ending up with a total of 2 bacteria. Then, it expresses that 4 reproductions were performed, that is, 4 bacteria were derived from both of the previous 2 bacteria, and a total of 10 bacteria were reached.).

4. The bacteria that have emerged after the bacterial reproduction should be identified by a different letter. The bacterium at the starting position is indicated as $A$, while the subsequent reproduction processes are shown in the order of $B, C, D, E, F, G, H$... etc. 
Gök, M. (2020). Introducing the fundamental theorem of arithmetic through a mobile game. New Trends and Issues Proceedings on Humanities and Social Sciences. 7(1), pp 249-262. DOI: 10.18844/prosoc.v\%vi\%i.4940

A Sample Game: Game $\mathrm{A}_{i}^{-1} \mathrm{~B}_{i}^{-1} \mathrm{C}_{i}^{-j} \mathrm{D}_{2}^{\prime} \mathrm{E}$

5.

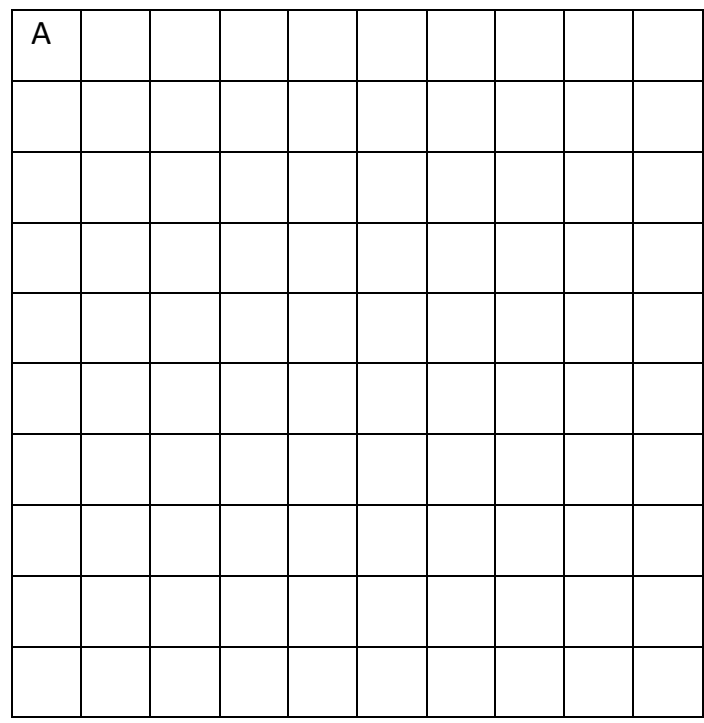

\begin{tabular}{|c|c|c|c|c|c|c|c|c|c|}
\hline A & B & C & C & C & C & C & C & C & C \\
\hline D & D & D & D & D & D & D & D & D & D \\
\hline E & E & E & E & E & E & E & E & E & E \\
\hline E & E & E & E & E & E & E & E & E & E \\
\hline E & E & E & E & E & E & E & E & E & E \\
\hline E & E & E & E & E & E & E & E & E & E \\
\hline & & & & & & & & & \\
\hline & & & & & & & & & \\
\hline & & & & & & & & & \\
\hline & & & & & & & & & \\
\hline
\end{tabular}

